Seventh Mceting, May 13th, 1887.

George Thom, Eisq., LL.D., President, in the Chair.

Some Correspondence betwoen Robert Simson, Professor of Mathematics in the University of Glasgowr, and Matthew Stewart, Professor of Mathematios in the University of Edinburgh.

By James Taylor, M.A.

This correspondence, purchased at the sale of the Gibson-Craig collection of MSS., is now in the possussion of Dr J. S. Mackay.

\title{
An Experiment in the Teaching of Geometry.
}

By A. Y. Fraser, M.A., F.R.S.E.

$\$ 1$. The course of geometry here referred to was given to pupils in George Heriot's School in the session preceding that in which they should begin the usual sygtematic study of geometry. The chief object of the course was to furnish their minds with a number of geometrical ideas before they should met with these ideas as treated by Euclid. Subsidiary ends were also kept in view - such as to get them to make neat and accurate figures, and to enable them to solve various practical problems of construction and measurement.

82. The classes with whom the experiment was tried were three in number, containing each fifty boys. The average age of the boys at the middle of the session was $12 \cdot 3,13 \cdot 2$ and 13 years. The time given was one period of forty-five minutes per week.

\$. The school provided filty pairs of compasses and fifty boxwood rulers ( $9 f^{\prime \prime}$ long, of special design, $l^{\prime \prime}$ at each end being unmarked and the inches being divided into 8 ths, 10ths, 12 ths, and 16ths). Each pupil had a note-book about the size of an ordinary copy hook, ruled in squares $b^{\prime \prime} \times \frac{1}{3}$. 